\title{
Effect of Caregiver's Health Education on Patterns of Self-Management and Glycemic Control in Pediatric Type 1 Diabetes
}

\author{
${ }^{1}$ Lamiaa Lofty Elhawy, ${ }^{2}$ Yasmin Husseiny Hassan Hussein, ${ }^{1}$ Seham Mahmoud Eldeeb \\ ${ }^{1}$ Community Medicine, ${ }^{2}$ Family medicine Faculty of Medicine, Zagazig University \\ Submitted:4-09-2020 Revised:2-20-2020 Accepted:2-10-2020
}

\begin{abstract}
Background: Type I diabetes mellitus (T1DM) is a lifelong disease that affects all aspects of diseased children's life and thus can negatively affect their mental, physical health and their health-related quality of life. Effective self-management of type 1 diabetes in pre-adolescent and adolescent years is important to prevent diabetes-related complications later in life. Objectives: to assess self-management patterns among caregivers of type 1 diabetic children pre and post health education about management of pediatric Type 1 diabetes mellitus and to assess glycemic control pre and post health education among children attending Zagazig university diabetes clinic. Method: An educational intervention (pre-test/post-test) study was carried out from the first of August 2019 to the end of March 2020 for Caregivers of Type 1 Diabetes children who attend Zagazig diabetes clinic for receiving periodic insulin therapy and regular checkup. Results: Self-Management patterns had significantly changed throughout the study as adaptive pattern increased from $22.4 \%$ pre-intervention to $36.8 \%$ and $44.3 \%$ post-intervention at 3 and 6 months respectively. On other hand, maladaptive pattern decreased from $20.8 \%$ pre-intervention to $7.9 \%$ and $6.6 \%$ post-intervention at 3 and 6 months respectively. Glycemic control had significantly improved throughout the study. Percentage with good glycemic control increased from $57.6 \%$ pre-intervention to $62.3 \%$ and $70.8 \%$ postintervention at 3 and 6 months respectively. Conclusion: The study illustrated that selfmanagement among caregivers of Type 1 Diabetes children as well as the children's glycemic control improved after health education. Adaptive Self-Management pattern was significantly associated with good glycemic control.
\end{abstract}

Keywords: caregiver, health education, Self-Management, Glycemic Control, Type 1 Diabetes

Corresponding Author: Lamiaa Lotfy El Hawy Email: lamiaa102elhawy @yahoo.com

\section{Introduction}

Type 1 diabetes mellitus (T1DM) is one of most common chronic pediatric diseases in which pancreatic islets are gradually destroyed in genetically susceptible individuals; ${ }^{1 ;}$ leading to loss of insulin secretion. $^{2}$

Various studies have shown a rising incidence of type 1 diabetes in children around the world. ${ }^{3-5}$ A study carried out in three Egyptian governorates (Fayoum, North Sinai, and Suez) showed that the prevalence rate of T1DM among children and adolescents $0.7 / 1000$ and the incidence rate was 4.01/100 000. ${ }^{6}$ Another study which carried out in Menoufia governorate showed that the prevalence rate of juvenile DM among school age children was $3.75 / 1000 .^{7}$

Type I diabetes mellitus (T1DM) is lifelong disease that affects all aspects of diseased children's life and thus can negatively affect their mental, physical 
health and their health-related quality of life (HRQOL). ${ }^{8}$

Management of T1DM requires lifelong insulin replacement therapy via an insulin pump or subcutaneous injection multiple times a day. If not managed correctly, long-term complications include retinopathy, neuropathy, cardiovascular disease, foot damage, and kidney difficulties. ${ }^{9}$ So, it requires changes in the behavior of the whole family and the responsibility falls mainly upon the mother. ${ }^{10}$

Achieving and sustaining a good glycemic control in a child with type 1 diabetes (T1DM) is a big challenge. As the child with diabetes grows, he undergoes a variety of physical, psychological and life style changes. Empowering the child and his family to take the reins of diabetes management in their hands is the single most important intervention to improve glycemic control and quality of life. ${ }^{11}$

Many studies showed that diabetes education program carried out at many Centers to the children with T1DM and their caregivers is feasible and very successful. ${ }^{12}$

Daily self-management requires planning and correct and timely execution of tasks, which are difficult in general and demands higher-order cognitive skills with a prominent role for executive functioning (EF). ${ }^{13}$ Therefore, parents of type 1 diabetic children have the responsibility of Effective self-management at first then the children become responsible when they grow up. ${ }^{14}$ Effective self-management of type 1 diabetes in pre- adolescent and adolescent years is important to prevent diabetes-related complications later in life. $^{15}$

The increased prevalence of type 1 diabetes mellitus in children with its complications, that affect the expectancy of their lives and adversely affecting their quality of life that lead to worsening of their compliance and adherence to the treatment with subsequent hazards. Implementation of an educational program to the newly diagnosed T1DM children and their caregivers is very important for improving the diabetes self-management patterns and glycemic control as well as the long term clinical outcome among this target group. Few studies had investigated the role of caregiver in self-management of type 1 diabetes.

The aim of this study was to assess selfmanagement patterns among caregivers of type 1 diabetic children pre and post health education about management of pediatric Type 1 diabetes mellitus and to assess glycemic control pre and post health education among children attending Zagazig diabetes clinic.

\section{Method}

An educational intervention (pre-test/posttest) study was carried out from the first of August 2019 to the end of March 2020 for Caregivers of Type 1 Diabetes children who attend for receiving periodic insulin therapy and regular checkup in Zagazig diabetes clinic, Egypt. This clinic provides free curative services for diabetic patients who are residing in Sharkia governorate. These services include health insurance curative services of school children with chronic diseases.

Sample size was calculated by EPI INFO $\mathrm{TM}{ }^{\mathbf{1 6}}$ assuming that percentage of adaptive Pattern of Self-Management in Pediatric Type 1 Diabetes was (18\%) before intervention versus (41.8\%) after intervention. ${ }^{17}$ Sample size was (114) with 95\% confidence level and $80 \%$ study power. We increased the sample by $10 \%$ to mitigate risk of dropout throughout the study.

Inclusion criteria: caregivers having a child or more than one child with diabetes, 
his age 6-12 years old, diabetic for at least 1 year. Exclusion criteria: monogenic diabetes of the young (MODY), presence of potential causes of Type 1 Diabetes e.g. corticosteroid therapy, cystic fibrosis.

Eligible participants were randomly selected from the daily clinic list and contacted by clinic personnel to ask about their interest in the study and then were approached by research staff during a regularly scheduled outpatient clinic visits.

The study was carried out throw three phases:

$1^{\text {st }}$ phase: Baseline data were collected: socio-demographic data, Diabetes SelfCare Inventory (SCI), last Hemoglobin A1c (HbA1c) and contact information.

Fahmy et al., $2015^{18}$ questionnaire was used to assess the socio-demographic characteristics.

Self-Care Inventory (SCI) ${ }^{19}$ is defined as the daily regimen tasks that the individual performs to manage diabetes. It consists of a 13-item self-report measure which was developed to assess patients' perceptions of the degree to which they adhere to treatment recommendations for their diabetes self-care .The SCI has been used with children and adolescents with Type 1 diabetes; for preadolescent children, parents are the informants for their child's level of self-care. It consists of four subscales (blood glucose testing and monitoring, insulin and food regulation, exercise, and emergency precautions). It contained items of five points likert scale. A total self-management score (maximum score was 65) was determined by summing all products. Regarding Self-Care Inventory, cut off points were: less than $50 \%$ (means maladaptive selfmanagement), from 50\%- 75\% (consider Moderate adaptive self-management) and more than $75 \%$ ( consider Adaptive selfmanagement'). ${ }^{20}$
Self-management patterns were classified into three types ${ }^{21}$ : (1) "Maladaptive selfmanagement" Defined as having difficulties in nearly all diabetes management areas as measured by SCI. (2) "Moderate adaptive self-management" It was defined as having difficulties in managing one or more diabetes management areas but not necessarily difficulties in all diabetes management areas. (3) 'Adaptive self-management' has been described as having little to no diabetes management deficits.

The questionnaire was translated to Arabic and back translated to English by language experts. The reliability of the scales was tested through measuring their internal consistency. It demonstrated a good level of reliability (Cronbach alpha $=0.82$ )

Hemoglobin A1c (HbA1c) was measured at baseline and after 3 and 6 months at the diabetes clinic laboratory. Hemoglobin A1c below $6.4 \%$ was considered as good glycemic control. ${ }^{22}$

$2^{\text {nd }}$ phases: Health education sessions were introduced after data collection. The first session was face to face in diabetic clinic took about 20 minutes in which we explained main items and gave caregivers health education booklet and how we will communicate with them online. The frequent sessions were through face book group containing all participants of care givers, where we did live videos and provided them with different heath education message methods like photos, videos, small quiz and finally, we asked them for any questions or explanations

Heath education message was designed according to American Diabetes Association (ADA) "Standards of Medical Care in Diabetes" for management of type 1 diabetes in children. ${ }^{23}$ The message included: blood glucose monitoring and management (how and importance), Blood/Urinary Ketone Monitoring (how 
and importance), Comprehensive nutrition education ( healthy eating , Monitoring carbohydrate intake, whether by carbohydrate counting.....), Approaches for Physical Activity and Exercise( types of Exercise suitable for them, importance of Physical Activity and how to prevent hypoglycemia during exercise ), child behavior and mental health, development and diabetes demands and priorities across childhood, Management of complications.

\section{Table (1): Socio-Demographic} Characteristics of Study Participants

\begin{tabular}{|c|c|}
\hline Caregivers $(n=117)$ & $\mathbf{N}(\%)$ \\
\hline $\begin{array}{l}\text { Type of caregiver: } \\
\text { Mother } \\
\text { Father } \\
\text { Other family member }\end{array}$ & $\begin{array}{r}99(84.6) \\
12(10.3) \\
6(5.1) \\
\end{array}$ \\
\hline $\begin{array}{l}\text { Educational level: } \\
\text { Illiterate / Read \&Write } \\
\text { Primary / Secondary } \\
\text { University }\end{array}$ & $\begin{array}{r}0(0.0) \\
50(42.7) \\
67(57.3)\end{array}$ \\
\hline $\begin{array}{l}\text { Socio-economic level of } \\
\text { family: } \\
\text { Low } \\
\text { Middle } \\
\text { High }\end{array}$ & $\begin{array}{l}15(12.8) \\
47(40.2) \\
55(47.0)\end{array}$ \\
\hline Diabetic children $(n=125)$ & \\
\hline $\begin{array}{l}\text { Age (years): } \\
\text { Mean } \pm \text { SD }\end{array}$ & $8.7 \pm 1.9$ \\
\hline $\begin{array}{l}\text { Gender: } \\
\text { Male } \\
\text { Female }\end{array}$ & $\begin{array}{l}65(52.0) \\
60(48.0)\end{array}$ \\
\hline $\begin{array}{l}\text { Education stage: } \\
\text { Primary } \\
\text { Preparatory }\end{array}$ & $\begin{array}{r}111(88.8) \\
14(11.2) \\
\end{array}$ \\
\hline $\begin{array}{l}\text { Age at diagnosis of DM } \\
\text { (years): } \\
\text { Mean } \pm \text { SD }\end{array}$ & $6.6 \pm 1.2$ \\
\hline $\begin{array}{l}\text { Duration of DM: } \\
\text { Less than } 1 \text { year } \\
\text { From } 1 \text { to } 2 \text { years } \\
\text { More than } 2 \text { years }\end{array}$ & $\begin{array}{l}41(32.8) \\
39(31.2) \\
45(36.0)\end{array}$ \\
\hline $\begin{array}{l}\text { Other } \\
\text { brother/sister: } \\
\text { Yes } \\
\text { No }\end{array}$ & $\begin{array}{r}16(12.8) \\
109(87.2)\end{array}$ \\
\hline BMI $\left(\mathrm{kg} / \mathrm{m}^{2}\right):$ & \\
\hline
\end{tabular}

\begin{tabular}{lr}
\hline Mean \pm SD & $22.2 \pm 2.7$ \\
\hline Other comorbidities: & \\
None & $85(68.0)$ \\
Hypothyroidism & $27(21.6)$ \\
Celiac disease & $13(10.4)$ \\
\hline Regimen of insulin & \\
therapy: & \\
Multiple daily injection & $125(100)$ \\
\hline
\end{tabular}

Continuous diabetes self-management education and support were established through Facebook group led by research staff.

$3^{\text {rd }}$ phase: Further assessment of diabetes self-management and glycemic control were done after 3 and 6 months.

Pilot study was done one month before data collection to detect any difficulties and to test content validity and reliability of the questionnaire after translation. It also helped to estimate time needed for data collection and expected frequency. The sample included in the pilot study was excluded from the main sample because of the changes that were done in the final version of the questionnaire.

An official permission from General Authority for Health Insurance was taken to Zagazig diabetes clinic. General Authority for Health Insurance was informed about the nature and steps of the study and written consent was taken from institutional managers.

\section{Ethical approval}

Approval of Institutional Review Board (IRB) of Zagazig University, Faculty of medicine was taken after revision of study protocol (ZU-IRB \#6348). The study participants were informed about the nature and the purpose of the study and verbal consent was taken before interview. All caregivers' and patient's data were confidential.

\section{Statistical analysis:}

The collected data were entered to and analyzed by computer using Statistical Package of Social Services, version 25 
(SPSS).$^{24}$ Data were presented in table as frequencies, proportions, mean and standard deviation. Friedman and Cochran $\mathrm{Q}$ tests were used to analyze dependent data of Self-Management patterns and glycemic control respectively. Pearson Chi square test, Chi Square for linear trend and Table (2): Self-Management Patterns and Glycemic Control of The Study Participants:

\begin{tabular}{|c|c|c|c|c|}
\hline \multirow[b]{2}{*}{ Outcome } & \multicolumn{2}{|c|}{ Post-intervention } & \multirow[b]{2}{*}{$\begin{array}{c}\text { Test of } \\
\text { sig. }\end{array}$} & \\
\hline & $\begin{array}{c}\text { At } 3 \text { months } \\
(n=114) \\
N(\%)\end{array}$ & $\begin{array}{c}\text { At } 6 \text { months } \\
(n=106) \\
N(\%)\end{array}$ & & \\
\hline ve & $\begin{array}{r}42(36.8) \\
63(55.3) \\
9(7.9)\end{array}$ & $\begin{array}{r}47(44.3) \\
52(49.1) \\
\quad 7(6.6)\end{array}$ & $\begin{array}{c}\mathbf{F} \\
51.1\end{array}$ & $\begin{array}{c}<0.001 \\
\text { HS }\end{array}$ \\
\hline $\begin{array}{r}6.3 \\
5.8-11.5 \\
\end{array}$ & $\begin{array}{r}6.0 \\
5.5-9.3 \\
\end{array}$ & $\begin{array}{r}5.9 \\
5.5-7.9 \\
\end{array}$ & $\begin{array}{c}\mathbf{F} \\
4.8\end{array}$ & $\begin{array}{c}0.01 \\
\mathrm{~S}\end{array}$ \\
\hline $\begin{array}{l}\text { Glycemic control: } \\
\text { Good } \\
\text { Bad }\end{array}$ & $\begin{array}{l}71(62.3) \\
43(37.7) \\
\end{array}$ & $\begin{array}{l}75(70.8) \\
31(29.2) \\
\end{array}$ & $\begin{array}{c}\mathbf{Q} \\
33.1\end{array}$ & $\begin{array}{c}<0.001 \\
\text { HS }\end{array}$ \\
\hline Dropout & $11(8.8)$ & $8(6.4)$ & & - \\
\hline $\begin{array}{l}\text { Most of caregivers were mothers }(84.6 \%) \text {, } \\
\text { only } 6.8 \% \text { of the studied caregivers had } \\
\text { more than one diabetic sibling, more than } \\
\text { half had high educational level and } 47.0 \% \\
\text { had high Socio-economic level (Table } 1 \text { ). } \\
\text { Mean age of diabetic children was } 8.7 \\
\text { years old, male to female ratio was almost } \\
1: 1 \text {, most of them }(88.8 \% \text { ) were primary } \\
\text { stage students, mean age at diagnosis was } \\
6.6 \text { years old, mean BMI was } 22.2 \mathrm{~kg} / \mathrm{m}^{2} \text {. } \\
\text { Some of children had other comorbidities, } \\
\text { mainly Hypothyroidism (21.6\%) and } \\
\text { Celiac disease (10.4\%). All of them had } \\
\text { multiple daily insulin injection regimens } \\
\text { (Table } 1 \text { ). } \\
\text { Self-Management patterns } \\
\text { significantly changed throughout the study } \\
\text { as adaptive pattern increased from } 22.4 \%\end{array}$ & 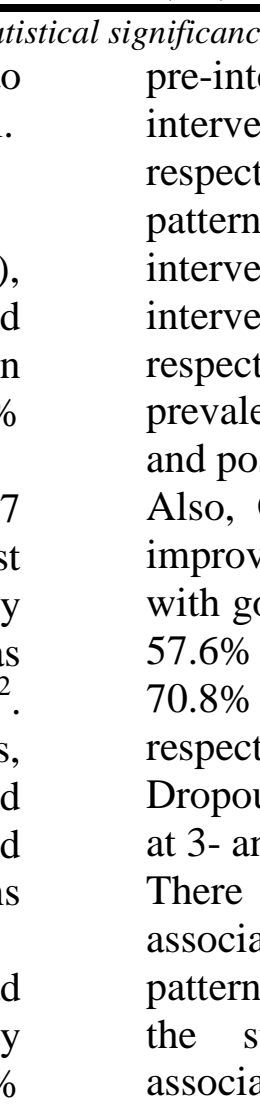 & $\begin{array}{l} \\
\text { rrvention to } 36 . \\
\text { ntion at } 3 \\
\text { ively. On other } \\
\text { decreased } \\
\text { ntion to } 7.9 \% \\
\text { thion at } 3 \\
\text { ively. Mixed p } \\
\text { nt Self-Manage } \\
\text { st-intervention p } \\
\text { Glycemic contr } \\
\text { ed throughout tl } \\
\text { od glycemic co } \\
\text { pre-interventic } \\
\text { post-interventio } \\
\text { ively (Table 2). } \\
\text { it rate was } 15.2 \\
\text { d 6-months pos } \\
\text { were high st } \\
\text { tion between } \\
\text { s and Glycemic } \\
\text { udy. Maladap } \\
\text { ted with bad }\end{array}$ & $\begin{array}{l}8 \% \text { and } 4 \\
\text { and } \\
\text { hand, } n \\
\text { from } 20 \\
\text { and } 6 \\
\text { and } \\
\text { attern wa } \\
\text { ment pat } \\
\text { hases (Ta } \\
\text { ol had si } \\
\text { he study. } \\
\text { ntrol incr } \\
\text { on to } 6 \\
\text { n at } 3 \text { an } \\
2 \% \text { (8.8\% } \\
\text { t-interven } \\
\text { atistical } \\
\text { Self-M } \\
\text { control } \\
\text { tive pa } \\
\text { glycem }\end{array}$ & $\begin{array}{l}3 \% \text { post- } \\
\text { months } \\
\text { aladaptive } \\
8 \% \text { pre- } \\
6 \% \text { post- } \\
\text { months } \\
\text { the most } \\
\text { rn at pre- } \\
\text { le 2). } \\
\text { snificantly } \\
\text { ercentage } \\
\text { ased from } \\
.3 \% \text { and } \\
6 \text { months } \\
\text { and } 6.4 \% \\
\text { ion). } \\
\text { significant } \\
\text { inagement } \\
\text { hroughout } \\
\text { ern was } \\
c \text { control }\end{array}$ \\
\hline
\end{tabular}

fisher's exact were used to analyze qualitative independent data. Odds ratio and $95 \%$ confidence interval were used for risk assessment. Binary logistic regression analysis was used for prediction of improvement in Self-Management patterns. 
before and at 3 months and 6 months after intervention $(\mathrm{OR}=18.8,59.2 \quad \& \quad \infty)$ respectively (Table 3 ).

There were statistical significant associations between improvement in SelfManagement patterns at end of study and some socio-demographic characteristics of the studied children. Younger children $(<8$ years old) had more improvement compared with older children (48.9\% versus $27.3 \%, \mathrm{OR}=2.6$ ). Presence of Other diabetic brother/sister was associated with improvement in Self-Management patterns (OR=3.8) (Table 4).

Caregivers with Primary and Secondary education had more improvement compared with higher education $(59.0 \%$ versus $20.5 \%, \mathrm{OR}=5.6)$ (Table 4).

Families with low and middle Socioeconomic level had more improvement than

Table (3): Association between Self-Management Patterns and Glycemic Control

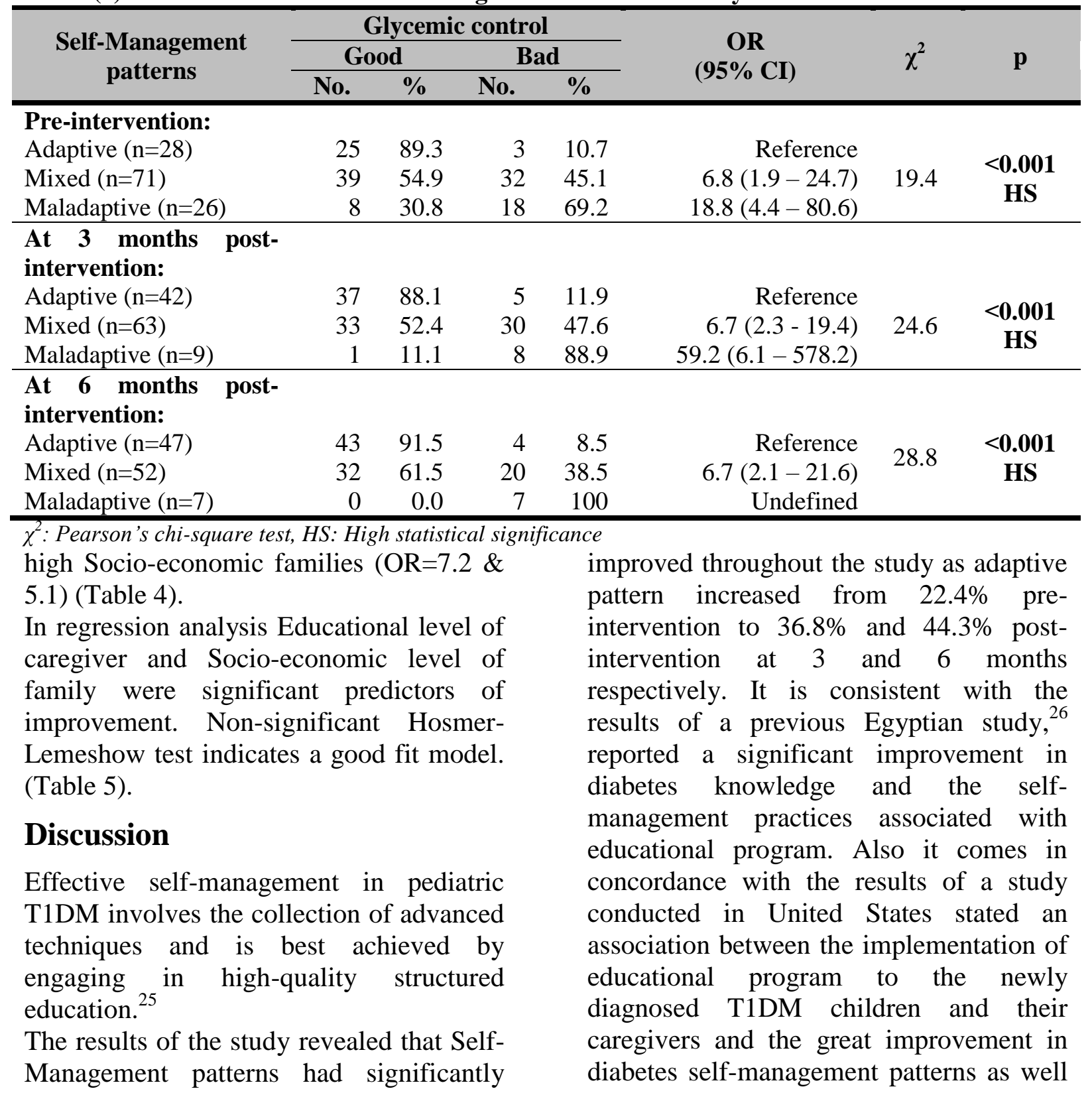


as the long term clinical outcome among this target group. ${ }^{27}$

Glycemic control had significantly improved throughout the study, as percentage of participants with good glycemic control increased from $57.6 \%$ pre-intervention to $62.3 \%$ and $70.8 \%$ postintervention at 3 and 6 months respectively. These results support the findings of previous studies, which strongly correlated glycemic control improvement to the development of a formalized diabetes education program and made it available to children with T1DM

Table (4): Association between Improvement in Self-Management Patterns at End of Study and Socio-Demographic Characteristics of The Studied Children

\begin{tabular}{|c|c|c|c|c|c|c|c|}
\hline \multirow[t]{2}{*}{$\begin{array}{l}\text { Socio-demographic } \\
\text { characteristics }\end{array}$} & \multicolumn{2}{|c|}{$\begin{array}{c}\text { Improved } \\
(\mathrm{n}=\mathbf{3 1})\end{array}$} & \multicolumn{2}{|c|}{$\begin{array}{c}\text { Not improved } \\
(n=47)\end{array}$} & \multirow[t]{2}{*}{$\begin{array}{c}\text { OR } \\
(95 \% \mathrm{CI})\end{array}$} & \multirow[t]{2}{*}{$\chi^{2}$} & \multirow[t]{2}{*}{$\mathbf{p}$} \\
\hline & No. & $\%$ & No. & $\%$ & & & \\
\hline $\begin{array}{l}\text { Age }(\text { years): } \\
<8 \text { years } \\
\geq 8 \text { years }\end{array}$ & $\begin{array}{r}22 \\
9 \\
\end{array}$ & $\begin{array}{l}48.9 \\
27.3 \\
\end{array}$ & $\begin{array}{l}23 \\
24 \\
\end{array}$ & $\begin{array}{l}51.1 \\
72.7\end{array}$ & $2.6(1.0-6.7)$ & 3.7 & $\begin{array}{c}0.05 \\
\mathrm{~S}\end{array}$ \\
\hline $\begin{array}{l}\text { Gender: } \\
\text { Male } \\
\text { Female }\end{array}$ & $\begin{array}{l}17 \\
14\end{array}$ & $\begin{array}{l}44.7 \\
35.0\end{array}$ & $\begin{array}{l}21 \\
26 \\
\end{array}$ & $\begin{array}{l}55.3 \\
65.0 \\
\end{array}$ & $1.5(0.6-3.7)$ & 0.7 & 0.4 \\
\hline $\begin{array}{l}\text { Education stage: } \\
\text { Primary } \\
\text { Secondary }\end{array}$ & $\begin{array}{r}30 \\
1 \\
\end{array}$ & $\begin{array}{l}40.0 \\
33.3\end{array}$ & $\begin{array}{r}45 \\
2 \\
\end{array}$ & $\begin{array}{l}60.0 \\
66.7\end{array}$ & $1.3(0.1-15.4)$ & fisher & 0.99 \\
\hline $\begin{array}{l}\text { Age at diagnosis of } \\
\text { DM (years): } \\
<6 \text { years } \\
\geq 6 \text { years }\end{array}$ & $\begin{array}{l}18 \\
13\end{array}$ & $\begin{array}{l}50.0 \\
31.0\end{array}$ & $\begin{array}{l}18 \\
29\end{array}$ & $\begin{array}{l}50.0 \\
69.0\end{array}$ & $2.2(0.9-5.6)$ & 2.9 & 0.08 \\
\hline $\begin{array}{l}\text { Duration of DM: } \\
\text { Less than } 1 \text { year } \\
\text { From } 1 \text { to } 2 \text { years } \\
\text { More than } 2 \text { years }\end{array}$ & $\begin{array}{r}15 \\
11 \\
5 \\
\end{array}$ & $\begin{array}{l}40.5 \\
44.0 \\
31.3 \\
\end{array}$ & $\begin{array}{l}22 \\
14 \\
11 \\
\end{array}$ & $\begin{array}{l}59.5 \\
56.0 \\
68.8 \\
\end{array}$ & $\begin{array}{r}\text { Reference } \\
1.2(0.4-3.2) \\
0.7(0.2-2.3) \\
\end{array}$ & 0.7 & 0.7 \\
\hline $\begin{array}{l}\text { Other diabetic } \\
\text { brother/sister: } \\
\text { Yes } \\
\text { No }\end{array}$ & $\begin{array}{r}7 \\
24 \\
\end{array}$ & $\begin{array}{l}70.0 \\
35.3\end{array}$ & $\begin{array}{r}3 \\
44 \\
\end{array}$ & $\begin{array}{l}30.0 \\
64.7\end{array}$ & $3.8(1.0-16.0)$ & 4.4 & $\begin{array}{c}\mathbf{0 . 0 3} \\
\mathrm{S}\end{array}$ \\
\hline $\begin{array}{l}\text { BMI }\left(\mathbf{k g} / \mathbf{m}^{2}\right): \\
\text { Normal } \\
\text { Underweight }\end{array}$ & $\begin{array}{r}7 \\
24 \\
\end{array}$ & $\begin{array}{l}35.0 \\
41.4\end{array}$ & $\begin{array}{l}13 \\
34 \\
\end{array}$ & $\begin{array}{l}65.0 \\
58.6 \\
\end{array}$ & $0.8(0.3-2.2)$ & 0.3 & 0.6 \\
\hline $\begin{array}{l}\text { Other comorbidities: } \\
\text { None } \\
\text { Hypothyroidism } \\
\text { Celiac disease }\end{array}$ & $\begin{array}{r}25 \\
3 \\
3\end{array}$ & $\begin{array}{l}47.2 \\
21.4 \\
27.3 \\
\end{array}$ & $\begin{array}{r}28 \\
11 \\
8\end{array}$ & $\begin{array}{l}52.8 \\
78.6 \\
72.7 \\
\end{array}$ & $\begin{array}{r}\text { Reference } \\
0.3(0.1-1.2) \\
0.4(0.1-1.8)\end{array}$ & 3.9 & 0.1 \\
\hline
\end{tabular}
the results of a study conducted in Saudi Arabia $^{30}$, which concluded that control of the level of HbAlc among the children studied was linked to the knowledge of their mothers.

Moreover, the results of the current study showed a high statistical significant association between Self-Management patterns and glycemic control as adaptive Self-Management pattern is linked to good glycemic control. This observation is consistent with the results of a previous 


\begin{tabular}{|c|c|c|c|c|c|c|c|}
\hline $\begin{array}{l}\text { Mother } \\
\text { Father } \\
\text { Other family member }\end{array}$ & $\begin{array}{r}29 \\
0 \\
2\end{array}$ & $\begin{array}{r}42.6 \\
0.0 \\
66.7\end{array}$ & $\begin{array}{r}39 \\
7 \\
1\end{array}$ & $\begin{array}{r}57.4 \\
100 \\
33.3\end{array}$ & $\begin{array}{r}\text { Reference } \\
\text { Undefined } \\
2.7(0.2-31.1)\end{array}$ & 5.8 & 0.06 \\
\hline $\begin{array}{l}\text { Educational level of } \\
\text { caregiver: }\end{array}$ & & & & & & & \\
\hline $\begin{array}{l}\text { Primary / Secondary } \\
\text { University }\end{array}$ & $\begin{array}{r}23 \\
8 \\
\end{array}$ & $\begin{array}{l}59.0 \\
20.5\end{array}$ & $\begin{array}{l}16 \\
31\end{array}$ & $\begin{array}{l}41.0 \\
79.5\end{array}$ & $5.6(2.0-15.2)$ & 12.0 & $\begin{array}{c}0.001 \\
\mathrm{~S}\end{array}$ \\
\hline $\begin{array}{l}\text { Socio-economic level } \\
\text { of family: } \\
\text { Low } \\
\text { Middle } \\
\text { High }\end{array}$ & $\begin{array}{r}8 \\
17 \\
6\end{array}$ & $\begin{array}{l}61.5 \\
53.1 \\
18.2\end{array}$ & $\begin{array}{r}5 \\
15 \\
27\end{array}$ & $\begin{array}{l}38.5 \\
46.9 \\
81.8\end{array}$ & $\begin{array}{r}7.2(1.7-29.9) \\
5.1(1.7-15.7) \\
\text { Reference }\end{array}$ & 11.4 & $\begin{array}{l}0.003 \\
\mathrm{~S}\end{array}$ \\
\hline
\end{tabular}

$\chi^{2}$ : Pearson's chi-square test, $S$ : Statistical significance N.B. Participants with adaptive pattern at the start of the study (Pre-intervention) and dropout participants (19 participants) were excluded from this table.

Improved Self-Management pattern: Shift to a higher level pattern (change of mixed to adaptive and change of maladaptive to mixed or adaptive)

Table (5): Binary Logistic Regression Analysis for Prediction of Improvement in Self-Management Patterns

\begin{tabular}{lcc}
\hline \multicolumn{1}{c}{ Predictors } & $\begin{array}{c}\text { OR } \\
(\mathbf{9 5 \%} \mathbf{C I})\end{array}$ & $\mathbf{P}$ \\
\hline Age (<8 years) & $\begin{array}{c}1.0 \\
(0.4-17.3)\end{array}$ & 0.3 \\
\hline $\begin{array}{l}\text { Presence of another } \\
\text { diabetic brother/sister }\end{array}$ & $\begin{array}{c}0.6 \\
(0.1-4.6)\end{array}$ & 0.6 \\
\hline $\begin{array}{l}\text { Educational level of } \\
\text { caregiver (Primary \& } \\
\text { Secondary) }\end{array}$ & $\begin{array}{c}3.7 \\
(1.3-10.6)\end{array}$ & $\mathbf{0 . 0 0 2}$ \\
\hline $\begin{array}{l}\text { Socio-economic level } \\
\text { of family (low \& } \\
\text { middle) }\end{array}$ & $\begin{array}{c}2.6 \\
(1.0-11.1)\end{array}$ & $\mathbf{0 . 0 1}$ \\
\hline
\end{tabular}

Hosmer and lemeshow test $=3.3, p$-value $=0.6$ study in India, which reported that the most essential strategy to improve glycemic control is to motivate the child and his or her family to take control of diabetes in their hands through an effective health education. ${ }^{31}$

Being a caregiver for a diabetic child of type 1 is a major challenge. ${ }^{32}$ Mothers identify a need for close monitoring and attention to the child's diabetes especially for those at very young age. ${ }^{33}$ As for the age of the children included in the study, the caregivers of younger children $(<8$ years of age) were approximately 3 times more likely to improve their selfmanagement patterns compared to older children. In addition, the improvement in Self-Management patterns was 4 times higher among caregivers with more than one diabetic child. One possible explanation of this may be due to the full burden of the complex daily management such as giving the insulin injections, finger bricks for blood glucose measurement and the difficulty of the young children in clearly describing and communicating their symptoms; being on the shoulders of the caregivers and doubling the burden on those with more than one diabetic child to be more responsive for the selfmanagement education. Also, in parallel with the results of the previous Norwegian study among diabetic children and their caregivers, improved blood glucose monitoring and improved glycemic control among children in the youngest age group were identified. ${ }^{34}$

This study reported that families with low and middle socio-economic status had a 7 and 5 times respectively greater likelihood of positive response to the health education program in the form of an improved selfmanagement patterns as compared to those with a high socio-economic status, As well as education as part of socio-economic measurement, the improvement in selfmanagement patterns among the less 
educated caregivers was about 6 times higher.

This finding is in line with the results of a previous study, which reported that people with low socio-economic status are motivated to change their lifestyle when they have experienced health complaints; health education interventions consider potential cost concerns when targeting individuals with low socio-economic status find good response and better adherence to health advice. ${ }^{35}$

On the contrary, a German study ${ }^{36}$, showed a significant association between socioeconomic status and diabetes selfmanagement patterns and glycemic control given that, low socio-economic status is linked to poor diabetes management and glycemic control with higher complications and bad outcomes.

Patients with low socio-economic status have a high hospital admission rate, reflecting the importance of individual education not only to the routine health education of this vulnerable group. ${ }^{37}$

\section{Conclusion}

The study illustrated that self-management among caregivers of Type 1 Diabetes children as well as the children's glycemic control improved after health education. Adaptive Self-Management pattern was significantly associated with good glycemic control. The self-management improvement was significantly more prevalent among caregivers who had younger children ( $<8$ years of age), had more than one child diagnosed as diabetic, less educated and with low socio-economic status.

Recommendation: The study sheds light on the importance of diabetes management education for caregivers. More efforts are required to support and maintain continuous training and education for the families of Type 1 Diabetes children for good glycemic control, improved quality of life and fewer hospital admissions.

Study limitations: Lack of cooperation by some child caregivers, but the researchers persuaded them to participate in the study after explaining the importance, objectives and methodology of the study. The Egyptian Diabetes Association guidelines were not used because we found that the American Diabetes Association guidelines were more recent, comprehensive, and conclusive and cited by majority of studies. It also was acknowledge by pediatric endocrinologists. Besides, The Egyptian Diabetes Association guidelines are adopted from ADA.

Acknowledgment: we would like to thank all the participants and all the staff in Zagazig diabetes clinic for their help to complete this work.

\section{References}

1. Wang Z, Xie Z, Lu Q, Chang C, Zhou Z. Beyond genetics: what causes type 1 diabetes. Clinical reviews in allergy \& immunology. 2017 Apr 1;52(2):273-86.

2. Larsson HE, Vehik K, Haller MJ, Liu X, Akolkar B, Hagopian W, Krischer J, Lernmark $\AA$, She JX, Simell O, Toppari J. Growth and risk for islet autoimmunity and progression to type 1 diabetes in early childhood: The Environmental Determinants of Diabetes in the Young Study. Diabetes. 2016 Jul 1;65(7):1988-95.

3. Patterson CC, Gyürüs E, Rosenbauer J, Cinek O, Neu A, Schober E, Parslow RC, Joner G, Svensson J, Castell C, Bingley PJ. Seasonal variation in month of diagnosis in children with type 1 diabetes registered in 23 European centers during 1989-2008: little short-term influence of sunshine hours or average temperature. Pediatric diabetes. 2015 Dec;16(8):573-80.

4. El Wakeel MA, Abou-el-asrar MO, Elkassas GM, Elabd MA, Zeid DA, Sabry RN, Awadallah EM. Urinary markers of oxidative DNA damage in type 1 diabetic children: 
relation to microvascular complications. Asian J Pharm Clin Res. 2017;10(10):318-22.

5. Mahmoodi H, Golboni F, Nadrian $H$, Zareipour M, Shirzadi S, Gheshlagh RG. Mother-father differences in postnatal psychological distress and its determinants in Iran. Open Access Macedonian Journal of Medical Sciences. 2017 Feb 15;5(1):91.

6. Salem M, El Sawi MA, Ibrahim WE, Abdel Aziz MM, Abdo KM, Ragab IA. Vitamin D receptor gene polymorphism and susceptibility to T1DM and its complications in Egyptian children. Egyptian J Pediatr. 2007;84:1-25.

7. Hassan FM, Khatab AA, El-Fotoh WM, Ganh IN. Prevalence of diabetes mellitus among school-age children. Menoufia Medical Journal. 2019 Jan 1;32(1):305.

8. Jaser SS, Patel N, Xu M, Tamborlane WV, Grey M. Stress and coping predicts adjustment and glycemic control in adolescents with type 1 diabetes. Annals of behavioral medicine. 2017 Feb 1;51(1):30-8.

9. Brinkman AK. Management of type 1 diabetes. Nursing Clinics. 2017 Dec 1;52(4):499-511.

10.Makara-Studzińska M, Somasundaram S, Ashraf GM, Gogacz M, Madej A, Izydorczyk B, Leszek J, Lebedeva SA, Chubarev VN, Tarasov VV, Kirkland E. Assessment of psychosocial functioning of mothers of children with diabetes mellitus compared to mothers of healthy children. BioMed Research International. 2019 Apr 9;2019.

11.Seth A. Challenges of Achieving an Optimum Glycemic Control in Children with Type 1 Diabetes in India. Diabetes. 2020 May $14 ; 6: 7$.

12.Xie Y, Liu F, Huang F, Lan C, Guo J, He J, Li L, Li X, Zhou Z. Establishment of a type 1 diabetes structured education programme suitable for Chinese patients: type 1 diabetes education in lifestyle and self adjustment (TELSA). BMC endocrine disorders. 2020 Dec;20(1):1-0.

13. Wasserman RM, Hilliard ME, Schwartz DD, Anderson BJ. Practical strategies to enhance executive functioning and strengthen diabetes management across the lifespan. Current Diabetes Reports. 2015 Aug 1;15(8):52.
14.Perez KM, Patel NJ, Lord JH, Savin KL, Monzon AD, Whittemore R, Jaser SS. Executive function in adolescents with type 1 diabetes: relationship to adherence, glycemic control, and psychosocial outcomes. Journal of Pediatric Psychology. 2017 Jul 1;42(6):636-46. 15.American Diabetes Association. 12. Children and adolescents: standards of medical care in diabetes-2018. Diabetes Care. 2018 Jan 1;41(Supplement 1):S126-36.

16.Center for Disease Control and Prevention. (2013). Epi InfoTM | CDC. https://www.cdc.gov/epiinfo/index.html.

17.Rohan JM, Pendley JS, Delamater A, Dolan L, Reeves G, Drotar D. Patterns of selfmanagement in pediatric type 1 diabetes predict level of glycemic control two years later. Journal of developmental and behavioral pediatrics: JDBP. 2013 Apr;34(3):186.

18.Fahmy SI, Nofal LM, Shehata SF, El Kady HM, Ibrahim HK. Updating indicators for scaling the socioeconomic level of families for health research. Journal of the Egyptian Public Health Association. 2015 Mar 1;90(1):1-7.

19.La Greca A. Manual for the self-care inventory. Miami, FL: University of Miami. 2004 Sep.

20.Barker I, Steventon A, Williamson R, Deeny SR. Self-management capability in patients with long-term conditions is associated with reduced healthcare utilisation across a whole health economy: crosssectional analysis of electronic health records. BMJ quality \& safety. 2018 Dec 1;27(12):98999.

21.Rohan JM, Delamater A, Pendley JS, Dolan L, Reeves G, Drotar D. Identification of selfmanagement patterns in pediatric type 1 diabetes using cluster analysis. Pediatric diabetes. 2011 Nov; 12(7):611-8.

22.Bergenstal RM, Gal RL, Connor CG, Gubitosi-Klug R, Kruger D, Olson BA, Willi SM, Aleppo G, Weinstock RS, Wood J, Rickels M. Racial differences in the relationship of glucose concentrations and hemoglobin A1c levels. Annals of internal medicine. 2017 Jul 18;167(2):95-102.

23.Chiang JL, Maahs DM, Garvey KC, Hood KK, Laffel LM, Weinzimer SA, Wolfsdorf JI, Schatz D. Type 1 diabetes in children and 
adolescents: a position statement by the American Diabetes Association. Diabetes Care. 2018 Sep 1;41(9):2026-44.

24.IBM. (2017). IBM SPSS Statistics for Windows, Version 25. Armonk, NY: IBM Corp. http://www01.ibm.com/support/docview.wss?uid=swg270 49428.

25.Heller SR, Gianfrancesco C, Taylor C, Elliott J. What are the characteristics of the best type 1 diabetes patient education programmes (from diagnosis to long-term care), do they improve outcomes and what is required to make them more effective? Diabetic Medicine. 2020 Apr;37(4):545-54.

26.Awad LA, Elghadban FE, El-Adham NA. Effect of an Intervention Program on Improving Knowledge and Self-Care Practices for Diabetic School-age Children. American Journal of Nursing. 2019 Feb 16;7(2):199-207. 27. Bernier A, Fedele D, Guo Y, Chavez S, Smith MD, Warnick J, Lieberman L, Modave F. New-onset diabetes educator to educate children and their caregivers about diabetes at the time of diagnosis: usability study. JMIR diabetes. 2018;3(2):e10.

28.Xie Y, Liu F, Huang F, Lan C, Guo J, He J, Li L, Li X, Zhou Z. Establishment of a type 1 diabetes structured education programme suitable for Chinese patients: type 1 diabetes education in lifestyle and self adjustment (TELSA). BMC endocrine disorders. 2020 Dec;20(1):1-0.

29.Campbell F, Lawton J, Rankin D, Clowes M, Coates E, Heller S, de Zoysa N, Elliott J, Breckenridge JP. Follow-up support for effective type 1 diabetes self-management (the FUSED model): a systematic review and metaethnography of the barriers, facilitators and recommendations for sustaining selfmanagement skills after attending a structured education programme. BMC health services research. 2018 Dec 1;18(1):898.

30.Campbell F, Lawton J, Rankin D, Clowes M, Coates E, Heller S, de Zoysa N, Elliott J, Breckenridge JP. Follow-up support for effective type 1 diabetes self-management (the FUSED model): a systematic review and metaethnography of the barriers, facilitators and recommendations for sustaining self- management skills after attending a structured education programme. BMC health services research. 2018 Dec 1;18(1):898.

31.Seth A. Challenges of Achieving an Optimum Glycemic Control in Children with Type 1 Diabetes in India. Diabetes. 2020 May $14 ; 6: 7$.

32.Iversen AS, Graue M, Haugstvedt A, Råheim M. Being mothers and fathers of a child with type 1 diabetes aged 1 to 7 years: a phenomenological study of parents' experiences. International journal of qualitative studies on health and well-being. 2018 Jan 1;13(1):1487758.

33.Sullivan-Bolyai S, Rosenberg R, Bayard M. Fathers' reflections on parenting young children with type 1 diabetes. MCN: The American Journal of Maternal/Child Nursing. 2006 Jan 1;31(1):24-31.

34.Haugstvedt A, Wentzel-Larsen T, Rokne B, Graue M. Perceived family burden and emotional distress: similarities and differences between mothers and fathers of children with type 1 diabetes in a population-based study. Pediatric diabetes. 2011 Mar;12(2):107-14.

35.Bukman AJ, Teuscher D, Feskens EJ, van Baak MA, Meershoek A, Renes RJ. Perceptions on healthy eating, physical activity and lifestyle advice: opportunities for adapting lifestyle interventions to individuals with low socioeconomic status. BMC Public Health. 2014; 14:1036.

36.Mönkemöller $\mathrm{K}$, Müller-Godeffroy $\mathrm{E}$, Lilienthal E, Heidtmann B, Becker M, Feldhahn L, Freff M, Hilgard D, Krone B, Papsch M, Schumacher A. The association between socio-economic status and diabetes care and outcome in children with diabetes type 1 in Germany: The DIAS study (diabetes and social disparities). Pediatric diabetes. 2019 Aug;20(5):637-44.

37.Konrad K, Vogel C, Bollow E, Fritsch M, Lange K, Bartus B, Holl RW, German/Austrian DPV Initiative and the competence network of diabetes. Current practice of diabetes education in children and adolescents with type 1 diabetes in Germany and Austria: analysis based on the German/Austrian DPV database. Pediatric diabetes. 2016 Nov;17(7):483-91. 
